\title{
PELAKSANAAN PEMENUHAN JAMINAN SOSIAL TENAGA KERJA SEBAGAI WUJUD PERLINDUNGAN HUKUM BAGI PEKERJA \\ (Hambatan dan Upaya Sistem Perjanjian Kerja Waktu Tertentu (PKWT) Di Kabupaten Murung Raya)
}

\author{
Rimluk S. Buhoy \\ DPRD Kabupaten Murung Raya, KALTENG \\ Email: rumuluksbuhoybni@yahoo.com
}

\begin{abstract}
One of the protection of human rights, namely the principles of freedom in the field of labor relations in Indonesia contained in Paragraph D of Article 28 (2) Constitution NRI 1945. The existence of labor as a human being has the same rights as other human beings in terms of getting and doing a job and receive a fair return. labor law protection must be provided and the responsibility of the government and their employers to be able to give it. So coveted labor welfare can be realized. classic problem that employers in the District Joyless Kingdom less attention to the fulfillment of the rights of labor which existed as a labor agreement with the system time. All the more so towards the fulfillment of workforce in the labor and social security programs are often overlooked.
\end{abstract}

Key words: protection of human rights, labour, employment agreements certain time, labor and social security

\begin{abstract}
Abstrak
Salah satu perlindungan hak asasi manusia, yaitu prinsip kebebasan di bidang hubungan kerja di Indonesia yang terkandung dalam Pasal 28 D ayat (2) UUD NRI 1945. Keberadaan tenaga kerja sebagai manusia memiliki hak yang sama dengan manusia lainnya dalam hal mendapatkan dan melakukan pekerjaan dan menerima imbalan yang adil. perlindungan hukum perburuhan harus disediakan dan tanggung jawab pemerintah dan majikan mereka untuk bisa memberikannya. Kesejahteraan pekerja jadi incaran dapat direalisasikan. masalah klasik yang pengusaha di Kabupaten Murung Raya kurang memperhatikan pemenuhan hak-hak tenaga kerja yang ada sebagai suatu perjanjian kerja dengan waktu sistem. Semua lebih terhadap pemenuhan tenaga kerja dalam program jaminan sosial tenaga kerja dan sering diabaikan.
\end{abstract}

Kata kunci: perlindungan hak asasi manusia, tenaga kerja, perjanjian kerja waktu tertentu, jaminan social tenaga kerja 


\section{Latar Belakang}

Hak asasi manusia adalah hak-hak dasar yang melekat pada diri manusia secara kodrati, universal dan langgeng sebagai anugerah Tuhan Yang Maha Esa, meliputi hak untuk hidup, hak berkeluarga untuk melanjutkan keturunan, hak mengembangkan diri, hak keadilan, hak kemerdekaan, hak keamanan, dan hak kesejahteraan yang berfungsi untuk menjaga integritas keberadaannya, sehingga tidak boleh diabaikan dan dirampas oleh siapapun. Rumusan tersebut jelas mengakui bahwa hak asasi adalah pemberian Tuhan Yang Maha Esa dan Negara Indonesia mengakui bahwa sumber hak asasi manusia adalah karunia Tuhan.

Hak asasi adalah bersifat universal, merata dan tidak dapat dialihkan kepada orang lain. Hak asasi dimiliki oleh seluruh umat manusia secara universal. Seseorang tidak akan pernah kehilangan hak asasinya karena orang itu tidak akan mungkin ia berhenti sebagai manusia. ${ }^{1}$ Konsep tentang hak asasi manusia bukan merupakan hal baru bagi bangsa Indonesia. Salah satu komitmen Indonesia terhadap penghormatan dan jaminan perlindungan hak asasi manusia terkandung dalam sila kedua Pancasila, dasar negara dan falsafah hidup bangsa Indonesia, yaitu "Kemanusiaan Yang Adil dan Beradab".

Salah satu perlindungan hak asasi manusia yaitu asas principle of liberty (prinsip kebebasan) dalam bidang hubungan kerja di Indonesia terdapat dalam Pasal 28 D Ayat (2) UUD NRI 45. Dalam Pasal tersebut disebutkan bahwa: "Setiap orang berhak untuk bekerja serta mendapat imbalan dan perlakuan yang adil dan layak dalam hubungan kerja”. Ketentuan ini mengandung pengertian bahwa setiap warga negara tanpa memandang segala perbedaan yang ada pada diri seseorang berhak mendapatkan dan melakukan pekerjaan serta menerima imbalan secara adil.

Begitu juga dengan keberadaan tenaga kerja sebagai seorang manusia memiliki hak sama dengan manusia lainnya dalam hal mendapatkan dan melakukan pekerjaan serta menerima imbalan secara adil. Tenaga kerja merupakan pelaku pembangunan dan pelaku ekonomi baik secara individu maupun secara kelompok, sehingga mempunyai peranan yang sangat signifikan dalam aktivitas perekonomian nasional, yaitu meningkatkan produktivitas dan kesejahteraan masyarakat.

Oleh karena itu, perlindungan hukum terhadap tenaga kerja wajib diberikan dan menjadi tanggungjawab pemerintah beserta pengusaha untuk dapat memberikannya. Sehingga kesejahteraan yang didambakan tenaga kerja dapat terwujud. Di sisi lain, perlindungan hukum terhadap tenaga kerja diperlukan karena tenaga kerja merupakan tulang punggung pembangunan yang dalam hal ini adalah pertumbuhan industri, sehingga kegiatan yang dilakukan mengandung aspek hubungan sosial, hubungan hukum, dan 
hubungan antar dan inter organisasi yang dapat menimbulkan hak dan kewajiban dan dilaksanakan berdasarkan nilai-nilai yang terkandung dalam Pancasila.

Berdasarkan Pasal 27 ayat 2 UUD 45 Jo. Pasal 1 angka (2) Undang-undang Nomor 13 Tahun 2003 Tentang Ketenagakerjaan (UU Ketenagakerjaan) disebutkan bahwa Tenaga Kerja adalah: "Setiap orang yang mampu melakukan pekerjaan guna menghasilkan barang dan/atau jasa baik untuk memenuhi kebutuhan sendiri maupun untuk masyarakat". Sehingga diperlukan suatu sikap sosial yang mencerminkan persatuan nasional, kegotongroyongan, tenggang rasa, dan pengendalian diri, serta sikap mental dari pelaku dalam proses produksi yaitu sikap saling menghormati dan saling mengerti serta memahami hak dan kewajibannya masingmasing. Beginilah hubungan ideal yang diinginkan antara tenaga kerja dan pengusaha.

Atas dasar cita-cita mulia tersebut, maka perlindungan yang diberikan bagi tenaga kerja sudah seharusnya diterima oleh semua tenaga kerja tanpa membeda-bedakan statusnya, baik ia berstatus sebagai tenaga kerja tetap (sistem Perjanjian Kerja Waktu Tidak TententuPKWTT) ataupun tenaga kerja dengan status kontrak/Perjanjian Kerja Waktu TertentuPKWT/Outsourcing.

Mengenai keberadaan tenaga kerja dengan sistem PKWT sebagaimana yang diatur dalam UU Ketenagakerjaan. Tenaga kerja kontrak atau karyawan kontrak diartikan sebagai perjanjian kerja waktu tertentu
(PKWT), hal ini tertuang dalam Pasal 56 sampai dengan Pasal 60 UU Ketenagakerjaan. Menurut Keputusan Menteri Tenaga Kerja dan Transmigrasi No. 100/MEN/IV/2004 Tentang Pelaksanaan perjanjian Kerja Waktu Tertentu, PKWT adalah: "Perjanjian kerja antara pekerja dengan pengusaha untuk mengadakan hubungan kerja dalam waktu tertentu atau untuk pekerjaan tertentu". Waktu tertentu disini maksudnya adalah perjanjian kerja yang dibatasi oleh jangka waktu tertentu. Jangka waktu tertentu untuk PKWT ini diatur dalam Pasal 59 ayat (4) UU Ketenagakerjaan yaitu untuk paling lama 2 tahun dan boleh diperpanjang 1 kali untuk paling lama 1 tahun.

Kemudian mengenai pekerjaan tertentu disini maksudnya adalah pengusaha hanya boleh mempekerjakan karyawan kontrak berdasarkan pada empat jenis dan sifat pekerjaan saja yaitu, a). Pekerjaan yang selesai sekali atau sementara sifatnya, b). Pekerjaan yang diperkirakan penyelesaiannya paling lama tiga tahun, c). Kegiatan baru, atau produk tambahan yang masih percobaan atau penjajakan (Pasal 59 ayat 1 UU Ketenagakerjaan).

Dengan adanya tenaga kerja kontrak melalui sistem PKWT, menimbulkan masalah dalam pelaksanaannya. Salah satunya berimplikasi pada pemenuhan terhadap hak-hak tenaga kerja kontrak yang sering diabaikan oleh pengusaha. Padahal dalam Pasal 6 UU Ketenagakerjaan, "Mewajibkan para pengusaha untuk memberikan hak dan kewajiban tenaga kerja tanpa membedakan 
jenis kelamin, suku, ras, agama, warna kulit, dan aliran politik". Hak tersebut dapat artikan salah satunya adalah hak untuk mendapatkan perlindungan hukum tenaga kerja, seperti: ${ }^{2}$

1. Perlindungan ekonomis, yaitu perlindungan tenaga kerja dalam bentuk penghasilan yang cukup, termasuk bila tenaga kerja tidak mampu bekerja di luar kehendaknya;

2. Perlindungan sosial, yaitu perlindungan tenaga kerja dalam bentuk jaminan kesehatan kerja, kebebasan berserikat dan perlindungan hak untuk berorganisasi; dan

3. Perlindungan teknis, yaitu perlindungan tenaga kerja dalam bentuk keamanan dan keselamatan kerja.

Dengan kata lain, perlindungan tersebut dapat diimplementasikan dalam bentuk Jaminan Sosial Tenaga Kerja (Jamsostek). Dalam Pasal 1 Undang-undang Nomor 3 Tahun Tentang Jaminan Sosial Tenaga Kerja (Jamsostek), yang dimaksud dengan Jaminan Sosial Tenaga Kerja adalah:

Suatu perlindungan bagi tenaga kerja dalam bentuk santunan berupa uang sebagai pengganti sebagian dari penghasilan yang hilang atau berkurang dan pelayanan sebagai akibat peristiwa atau keadaan yang dialami oleh tenaga kerja berupa kecelakaan kerja, sakit, hamil, bersalin, hari tua, dan meninggal dunia.

Bentuk perlindungan, pemeliharaan maupun peningkatan kesejahteraan dimaksud diselenggarakan dalam bentuk progam jaminan sosial tenaga kerja yang bersifat dasar dengan berasaskan usaha bersama, kekeluargaan dan gotong royong sebagaimana terkandung dalam jiwa dan semangat Pancasila dan UUD 1945. Pada hakekatnya progam jaminan sosial tenaga kerja ini memberikan kepastian berlangsungnya asas penerimaan penghasilan keluarga sebagai pengganti sebagian atau seluruh penghasilan yang hilang.

Namun, perlindungan tersebut sebagian besar hanya berlaku bagi pekerja dengan status tetap atau yang terikat dengan sistem PKWTT. Sedangkan bagi tenaga kerja dengan sistem PKWT pengaturannya hanya diatur dalam Keputusan Menteri Republik Indonesia Nomor: KEP-150/MEN/1999 Tahun 1999 Tentang Penyelenggaraan Program Jaminan Sosial Tenaga Kerja Bagi Tenaga Kerja Harian Lepas, Borongan dan Perjanjian Kerja Waktu Tertentu.

Dengan regulasi yang demikian menimbulkan permasalahan yang hampir terjadi di seluruh wilayah Republik Indonesia, tak terkecuali di Kabupaten Murung Raya Provinsi Kalimantan Tengah. Menjadi suatu persoalan klasik bahwa pengusahapengusaha di Kabupaten Murung Raya kurang memperhatikan pemenuhan hak-hak tenaga kerja yang berstatus sebagai tenaga kerja dengan sistem PKWT. Terlebih-lebih terhadap pemenuhan hak tenaga kerja dalam program Jamsostek, sering kali terabaikan. 
Berdasarkan uraian latar belakang masalah tersebut di atas, rumusan masalah yang akan menjadi obyek pembahasan adalah sebagai berikut:

1. Bagaimana pelaksanaan pemenuhan hak Jamsostek sebagai wujud perlindungan hukum bagi tenaga kerja dengan sistem PKWT di Kabupaten Murung Raya?

2. Apa yang menjadi hambatan dalam pelaksanaan pemenuhan hak Jamsostek sebagai wujud perlindungan hukum bagi tenaga kerja dengan sistem PKWT di Kabupaten Murung Raya?

3. Apa saja upaya untuk mengatasi hambatan dalam pelaksanaan pemenuhan hak Jamsostek sebagai wujud perlindungan hukum bagi tenaga kerja dengan sistem PKWT di Kabupaten Murung Raya?

\section{Pembahasan}

\section{A. Pelaksanaan Pemenuhan Jamsostek sebagai Wujud Perlindungan Hukum Bagi Tenaga Kerja dengan Sistem PKWT Di Kabupaten Murung Raya}

Sebelum berlakunya UU Ketenagakerjaan, praktik penyediaan jasa tenaga kerja untuk dipekerjakan di perusahaan lain sudah terjadi. Bidang-bidang pekerjaan seperti satuan pengamanan (satpam-security) dan cleaning service merupakan pekerjaan yang diserahkan perusahaan untuk dikerjakan oleh tenaga kerja dari perusahaan lain. Praktik pelaksanaannya pun tidak berbeda dengan yang diatur dalam
UU Ketenagakerjaan. Praktek tenaga kerja dengan sistem PKWT atau yang lebih populer disebut pekerja kontrak/outsourcing di Indonesia, ditilik dari sejarahnya telah dilakukan bertahun-tahun yang lampau.

Keberadaan model atau sistem kerja seperti ini, membawa konsekuensi bagi tenaga kerja yang bersangkutan. Sebab, apabila kontrak diputus begitu saja, pekerja tidak dapat menuntut hak-haknya kepada perusahaan tersebut. Ketiadaan perlindungan bagi tenaga kerja telah membuat pandangan masyarakat menjadi negatif. Tenaga kerja dianggap sebagai barang komoditi yang dapat dijual, dipindah tangankan, ditukar, yang hanya diperhatikan apabila pengusaha menganggap dapat mempekerjakan tenaga kerja yang bersangkutan dan dapat disingkirkan begitu saja apabila pengusaha tidak memerlukannya lagi. $^{3}$

Kenyataannya, hingga masa-masa sekarang ini di mana tenaga kerja kesulitan mencari pekerjaan, tenaga kerja dihadapkan pada pilihan "take it or leave it" terhadap tawaran peluang pekerjaan dengan sistem PKWT atau tidak bekerja sama sekali. Ketiadaan pilihan tersebut, membuat tenaga kerja memutuskan untuk menerima sistem kerja PKWT ini. Walaupun perjanjian kerja tersebut bersifat waktu tertentu (PKWT) antara pemberi kerja dengan penerima kerja, yang pada umumnya dibatasi masa berlakunya, maka tidak ada kepastian kesinambungan

3 Andari Yurikosari, Pemutusan Hubungan Kerja di Indonesia, Fakultas Hukum Universitas Indonesia, Jakarta, hlm. 83-84. 
dalam pekerjaan sehingga tenaga kerja merasa terancam.

Persoalan yang muncul adalah bahwa setelah pekerjaan yang diperjanjikan selesai, maka otomatis para tenaga kerja akan berhenti bekerja. Oleh karena itu untuk menghindar dari kewajiban membayar gaji kepada tenaga kerja dalam hal tidak ada pekerjaan bagi tenaga kerja, pengusaha mensyaratkan kontrak kerja. Pada pelaksanaannya kontrak kerja dapat berlangsung secara bertahun-tahun dan walaupun hal tersebut bertentangan dengan undang-undang, pengusaha menempuh cara tersebut.

Terhadap situasi demikian, pemerintah dalam beberapa tahun terakhir telah memberikan perhatian terhadap permasalahan ketenagakerjaan. Dengan kata lain, kepentingan terhadap tenaga kerja mulai diperhatikan pada saat negara memasuki tahap negara kesejahteraan. Pada periode ini negara mulai memperhatikan antara lain kepentingan tenaga kerja, kemudian tuntutan terhadap intervensi pemerintah melalui pembentukan hukum yang melindungi pihak yang lemah sangatlah kuat. ${ }^{4}$

Untuk melindungi pekerja dari permasalahan ketenagakerjaan yang kompleks, pemerintah mengeluarkan Undang-undang Ketenagakerjaan. Di Indonesia Undang-undang tentang Ketenagakerjaan yang berlaku pada saat ini yaitu Undang-undang No. 13 Tahun 2003.
Mengenai perlindungan bagi pekerja secara umum dalam UU Ketenagakerjaan diatur mengenai perlindungan terhadap penyandang cacat, perlindungan terhadap perempuan, perlindungan terhadap waktu kerja, keselamatan dan kesehatan kerja, juga perlindungan dalam hal pengupahan dan dalam hal kesejahteraan.

Namun, perlindungan tersebut sebagian besar hanya berlaku bagi pekerja dengan status tetap atau yang terikat dengan sistem PKWTT. Sedangkan bagi tenaga kerja dengan sistem PKWT pengaturannya diatur dalam Keputusan Menteri Republik Indonesia Nomor: KEP-150/MEN/1999 Tahun 1999 tentang Penyelenggaraan Program Jaminan Sosial Tenaga Kerja Bagi Tenaga Kerja Harian Lepas, Borongan dan Perjanjian Kerja Waktu Tertentu.

Dengan regulasi yang demikian menimbulkan permasalahan yang hampir terjadi di seluruh wilayah Republik Indonesia, tak terkecuali di Kabupaten Murung Raya Provinsi Kalimantan Tengah. Menjadi suatu persoalan klasik bahwa pengusaha-pengusaha di Kabupaten Murung Raya kurang memperhatikan pemenuhan hak-hak tenaga kerja yang berstatus sebagai tenaga kerja dengan sistem PKWT. Terlebih-lebih terhadap pemenuhan hak tenaga kerja dalam program Jamsostek, sering kali terabaikan. Menurut Karyidadi Kepala Dinas Tenaga Kerja, Transmigrasi dan Sosial (Disnakertransos)

4 Erman Rajagukguk, Penemuan Hukum di Indonesia: Menjaga Persatuan, Memulihkan Ekonomi dan Memperluas Kesejahteraan Sosial, Pidato Dies Natalis dan Peringatan Tahun Emas Universitas Indonesia (1950-2000), Kampus UI Depok Jakarta, 5 Februari 2000, hlm. 14. 
Kabupaten Murung Raya, menjelaskan ini disebabkan oleh berbagai faktor, sehingga bahwa:

Pelaksanaan Program Jamsostek belum menunjukkan hasil yang menggembirakan. Berdasarkan data yang ada pada Bidang Ketenagakerjaan Disnakertransos Kabupaten Murung Raya, jumlah Perusahaan yang tidak mengikuti Program Jamsostek mencapai 50\% perusahaan. Padahal UU Jamsostek bersifat wajib bagi seluruh usaha berbadan hukum. ${ }^{5}$

Selanjutnya, menurut Karyidadi menjelaskan bahwa:

Kurangnya kesadaran pengusaha dalam melaksanakan Program Jamsostek disebabkan berbagai faktor, yang salah satunya terkait dengan penghematan pengeluaran keuangan perusahaan. Apalagi dibarengi dengan lemahnya pengawasan dan penegakan hukum bagi perusahaan-perusahaan yang tidak melaksanakan Program Jamsostek. ${ }^{6}$

Dengan keadaan demikian, saat ini di Kabupaten Murung Raya pelaksanaan program Jamsostek bagi tenaga kerja dengan sistem PKWT belum diimplementasikan sepenuhnya oleh perusahaan-perusahaan. Hal pelaksanaan sistem PKWT relatif terabaikan. Dan kondisi demikian memerlukan penanganan secara bersama-sama oleh pemangku kepentingan, baik pemerintah (pusat-daerah), asosiasi pengusaha maupun tenaga kerja itu sendiri.

\section{B. Hambatan Dalam Pelaksanaan}

\section{Pemenuhan Perlindungan Hukum}

Jamsostek Bagi Tenaga Kerja Dengan

Sistem PKWT Di Kabupaten Murung

Raya

Dalam pelaksanaan pemberian perlindungan terhadap para tenaga kerja dengan sistem PKWT tidak selalu bisa berjalan dengan baik sesuai dengan yang diharapkan dan diinginkan untuk terjadi oleh para pembuat undang-undang. Pada pelaksanaannya terdapat berbagai kendala yang menghambat tercapainya keinginan dari pembuat undang-undang.

Sekarang ini banyak pengusaha yang semakin berminat untuk menggunakan jasa tenaga kerja dengan sistem PKWT, karena pengusaha menilai lebih efisien memakai tenaga kerja dengan sistem PKWT jika di bandingkan dengan memakai jasa tenaga kerja dengan sistem PKWTT. Tidak hanya upah, tunjangan maupun uang pesangon yang terabaikan bagi tenaga kerja dengan sistem PKWT, tetapi juga termasuk pemenuhan

5 Hasil wawancara dengan Nara Sumber: Bapak Karyidadi, S.Sos, Kepala Dinas Tenaga Kerja, Transmigrasi dan Sosial (Disnakertransos) Kabupaten Murung Raya, Tanggal wawancara 29 September 2012.

6 Hasil wawancara dengan Nara Sumber: Bapak Karyidadi, S.Sos, Kepala Dinas Tenaga Kerja, Transmigrasi dan Sosial (Disnakertransos) Kabupaten Murung Raya, Tanggal wawancara 29 September 2012. 
hak tenaga kerja oleh perusahaan terhadap program Jamsostek. Menurut Heri Harsono, Kabid Ketenagakerjaan Disnakertransos Kabupaten Murung Raya, menjelaskan:

Diperkirakan memang ada perusahaan-perusahaan pengerah jasa tenaga kerja yang sengaja memanfaatkan sistem PKWT untuk menghindari dari kewajiban untuk memenuhi hak tenaga kerja terhadap program Jamsostek, membayar gaji secara tetap ataupun membayar pesangon ketika di PHK. Keadaan inilah yang kemudian menimbulkan keresahan di kalangan para tenaga kerja dengan sistem PKWT, dimana diketahui sebesar dua pertiga dari jumlah mereka yaitu tenaga kerja dengan sistem PKWT tidak memberi kepastian untuk terus dapat bekerja, dimana mereka dengan mudah untuk diberhentikan dengan berbagai alasan. $^{7}$

Adanya keadaan tersebut jelas tidak memberikanperlindunganterhadapparatenaga kerja yang bekerja dengan sistem PKWT, sedangkan seperti yang diketahui salah satu tujuan pembangunan ketenagakerjaan adalah memberikan perlindungan kepada tenaga kerja dalam mewujudkan kesejahteraan, yaitu sebagaimana yang telah diatur dalam Pasal 4 huruf c UU Ketenagakerjaan.
Hambatan-hambatan yang dialami dalam pelaksanaan program Jamsostek akan diuraikan dalam pembahasan di bawah ini.

\section{B.1. Hambatan yang Berkaitan} dengan Pengaturan Tentang Program Jamsostek bagi Tenaga Kerja dengan Sistem PKWT

Sebagaimana telah dijelaskan di atas, untuk melindungi pekerja dari permasalahan ketenagakerjaan yang kompleks, pemerintah mengeluarkan Undang-undang Ketenagakerjaan. Namun, perlindungan tersebut sebagian besar hanya berlaku bagi pekerja dengan status tetap atau yang terikat dengan sistem PKWTT (Perjanjian Kerja Waktu Tidak Tertentu). Terlebih lagi perlindungan hukum yang berkaitan dengan pemenuhan hak terhadap program Jamsostek bagi tenaga kerja yang berstatus PKWT, belum sepenuhnya terakomodir dalam UU Ketenagakerjaan. Bagi tenaga kerja dengan sistem PKWT pengaturannya hanya diatur dalam Keputusan Menakertrans Republik Indonesia Nomor: KEP-150/MEN/1999 tentang Penyelenggaraan Program Jaminan Sosial Tenaga Kerja Bagi Tenaga Kerja Harian Lepas, Borongan dan Perjanjian Kerja Waktu Tertentu.

Sesuai dengan Keputusan Menakertrans tersebut, diatur bahwa jenis program dan dasar penetapan iuran bagi tenaga kerja harian lepas:

7 Hasil wawancara dengan Nara Sumber: Bapak Heri Harsono, ST., SH., Kabid Ketenagakerjaan Dinas Tenaga Kerja, Transmigrasi dan Sosial (Disnakertransos) Kabupaten Murung Raya, Tanggal wawancara 29 September 2012. 
1. Pengusaha yang mempekerjakan tenaga kerja harian lepas kurang dari tiga bulan wajib mengikutsertakannya dalam program Jaminan Kecelakaan Kerja dan Jaminan Kematian;

2. Dalam hal pengusaha mempekerjakan tenaga kerja harian lepas untuk melakukan pekerjaan secara terus menerus selama tiga bulan berturut-turut atau lebih dan setiap bulannya tidak kurang dari 20 hari, maka wajib mengikutsertakannya dalam program Jaminan Kecelakaan Kerja, Jaminan Hari Tua, Jaminan Kematian dan Jaminan Pemeliharaan Kesehatan;

3. Kewajiban sebagaimana dimaksud, harus dilakukan terhitung sejak tenaga kerja harian lepas telah bekerja melewati masa kerja tiga bulan berturut-turut.

Khusus untuk Tenaga Kerja Harian yang hanya didaftarkan dalam program Jaminan Kecelakaan Kerja dan Jaminan Kematian, hanya memiliki nomor Peserta Jamsostek. Tetapi Kartu Peserta Jamsostek tidak diterbitkan. Karena Kartu Peserta Jamsostek akan diterbitkan apabila peserta telah mengikuti program Jaminan Hari Tua (JHT).

Selanjutnya, Pemerintah telah mengeluarkan Undang-undang No. 3 Tahun 1992 tentang Jaminan Sosial Tenaga Kerja (UU Jamsostek) untuk memberikan perlindungan kepada tenaga kerja dan keluarganya. Program Jamsostek berupa produk jasa, dimaksudkan untuk melindungi resiko sosial tenaga kerja yang dihadapi oleh tenaga kerja. Program tersebut terdiri dari:

a. Program Jaminan Kecelakaan Kerja (JKK);

b. Program Jaminan Hari Tua (JHT);

c. Program Jaminan Kematian (JKM);

d. Program Jaminan Pemeliharaan Kesehatan (JPK).

Demikian perdulinya pemerintah terhadap masalah ketenagakerjaan, khususnya tenaga kerja dengan sistem PKWT. Namun, permasalahan tetap saja terjadi di dunia hubungan industrial antara pengusaha dengan tenaga kerja. Sebagaimana dijelaskan di atas, perlindungan tersebut sebagian besar hanya berlaku bagi pekerja dengan status tetap atau yang terikat dengan sistem PKWTT. Sedangkan bagi pekerja dengan sistem PKWT belum sepenuhnya terlindungi.

Selain itu, konstruksi hukum yang tidak jelas dan tegas ikut mewarnai pensiasatan hukum oleh pihak-pihak yang memanfaatkan kelemahan atau ketidak-tegasan dari kaidah hukum dan menjauhkan dari asas equality before the law. Hukum bukanlah the rule of law, melainkan the rule by law. Di sini eksistensi hukum hanya sebagai alat untuk mengamankan kekuasaan pemilik modal yang berkedok moralis. Bukan hanya hukum yang dimanfaatkannya sebagai alat semata, melainkan peranan dari pemerintah yang seharusnya melaksanakan fungsi pengawasan, penindakan, dan fungsi menetapkan kebijakan tidak dapat berbuat sebagaimana mestinya. ${ }^{8}$ 
Tampaknya hukum yang semula dipergunakan sebagai alat kontrol tidak dapat dimanfaatkan secara optimal dalam melayani kepentingan masyarakat, dan khususnya tenaga kerja yang ingin mendambakan tegaknya hukum (the rule of law). Di sini efektifitas (pemberlakuan) hukum mulai dipertanyakan, dan khususnya tingkat keberhasilan dalam memberi pelayanan kepada masyarakat industrial.

\section{B.2. Kendala yang Berkaitan dengan Lemahnya Sistem Pengawasan}

Pengawasan ketenagakerjaan merupakan unsur penting dalam perlindungan terhadap tenaga kerja, sekaligus merupakan upaya penegakan hukum ketenagakerjaan secara menyeluruh. Di samping itu melalui pengawasan diharapkan agar pelaksanaan terhadap peraturan tentang ketenagakerjaan dapat berjalan sebagaimana mestinya. Dengan demikian melalui pengawasan yang dilakukan diharapkan dapat meniadakan atau memperkecil adanya pelanggaranpelanggaran terhadap UU Ketenagakerjaan, sehingga proses hubungan industrial dapat berjalan dengan baik dan harmonis.

Tugas pengawasan di bidang ketenagakerjaan dilakukan oleh Menteri Tenaga Kerja dan Transmigrasi dengan menunjuk pegawai pengawas yang memiliki kewajiban dan wewenang penuh dalam melaksanakan fungsi pengawasan dengan baik. Pelaksanaan pengawasan di bidang ketenagakerjaan ini dilakukan oleh unit kerja tersendiri pada instansi yang lingkup tugasnya dan tanggungjawabnya di bidang ketenagakerjaan, yaitu sebagaimana diatur dalam Pasal 178 ayat (1) UU Ketenagakerjaan.

Kendala yang dihadapi oleh badan pengawas ketenagakerjaan dalam pemberian perlindungan tenaga kerja dalam pelaksanaan pekerjaan dengan sistem PKWT, khususya pemenuhan hak terhadap program Jamsostek, menurut Heri Harsono adalah:

Karena ketidakjelasan peraturan yang mengatur tentang sistem PKWT, salah satunya adalah terhadap pembuatan kontrak kerja yang dilakukan perusahaan terhadap Tenaga Kerja PKWT. Di mana dalam kontrak kerja yang dicatatkan kepada kami sebagaimana yang disyaratkan oleh penjelasan Pasal 59 ayat (1) UU Ketenagakerjaan tersebut tidak pernah dijelaskan secara rinci apa pekerjan yang akan dilakukan, apakah sekali selesai atau pekerjaan yang merupakan promosi sehingga kami dari Disnakertransos Kabupaten Murung Raya memang kesulitan untuk memantau pekerjaan yang dilakukan oleh tenaga kerja PKWT, apalagi jumlah mereka ribuan orang. ${ }^{9}$

9 Hasil wawancara dengan Nara Sumber: Bapak Heri Harsono, ST., SH., Kabid Ketenagakerjaan Dinas Tenaga Kerja, Transmigrasi dan Sosial (Disnakertransos) Kabupaten Murung Raya, Tanggal wawancara 29 September 2012. 
Dengan demikian terlihat, bahwa dalam pelaksanaan terhadap ketentuan perundangundangan tenaga kerja, terutama yang berkaitan dengan pelaksanaan perlindungan terhadap tenaga kerja PKWT memang terdapat berbagai kendala, yang diantaranya adalah sebagaimana yang telah penulis kemukakan di atas.

\section{B.3. Belum Optimalnya Peran Pengawas Ketenagakerjaan}

Pengawasan ketenagakerjaan adalah suatu sistem pengawasan terhadap pelaksanaan peraturan perundangan ketenagakerjaan. Sistem ini adalah suatu tata jaringan yang terdiri dari unsur (sub sistem) yang mana satu dengan yang lainnya saling berkaitan, ketergantungan dan saling berhubungan dalam mencapai tujuan.

Hubungan dengan sistem pengawasan ketenagakerjaan ini terdapat beberapa sub sistem yaitu pola pendidikan, operasional, ketatalaksanaan serta mekanisme operasioanal pengawas ketenagakerjaan. Pola pendidikan ini menyediakan pengawas ketenagakerjaan baik umum maupun spesialis, sedangkan pola operasional merupakan pengaturan interaksi antar pegawai pengawas. Kemudian ketatalaksanaan merupakan pendukung administrasi pelaksanaan pengawasan ketenagakerjaan. Adapun mekanisme operasional pengawasan adalah urutan pemeriksaan atau pengawasan perusahaan di lapangan.

Dengan demikian tidak berjalan dengan baik salah satu sub sistem akan berakibat tidak berjalan sistem itu sendiri. Kaitannya dengan pengawasan ketenagakerjaan sebagaimana diketahui adalah perusahaan dan tenaga kerja. Untuk dapat dilaksanakan 2 (dua) objek tersebut secara tuntas maka pegawai pengawas ketenagakerjaan sebagai pegangan adalah sistem pengawasan kaitan dengan mekanisme operasional pengawasan ketenagakerjaan.

Berdasarkan temuan di apangan, katakanlah masalah lowongan dan PHK (Pemutusan Hubungan Kerja). Sebagai seorang pegawai pengawas ketenagakerjaan yang memahami akan sistem pengawasan tentu temuan-temuan tersebut akan ditindaklanjuti dengan cara mendistribusikan ke Subdit (tingkat pusat). Ditemukannya lowongan akan didistribusikan ke tempat kerja, sedang kasus PHK ke P4D begitu selanjutnya tergantung temuan yang didapat di apangan. Sedangkan kasus yang berkaitan dengan pengawasan misal upah lembur diselesaikan oleh pegawai pengawas yang bersangkutan.

Kemudian untuk kasus-kasus yang belum ada pengaturannya, didistribusikan ke biro hukum guna pembahasan lebih lanjut untuk diterbitkan undang-undang atau peraturan lainnya, di sinilah bagi para pegawai pengawas ketenagakerjaan dituntut suatu kemauan akan pelaksanaan sistem pengawas ketenagakerjaan. Bila ini dipenuhi maka pegawai pengawas sebagai ujung tombak, mata hukum (law of eyes) serta sumber data akan terwujud.

Karenanya, untuk meminimalisir kesalahan-kesalahan dalam penyelenggaraan 
pengawasan tenaga kerja dan mengoptimalkan fungsi pengawasan tersebut, presiden mengeluarkan Peraturan Presiden Republik Indonesia Nomor 21 Tahun 2010 tentang Pengawasan Ketenagakerjaan. Dikatakan dalam Perpres Pengawasan Ketenagakerjaan tersebut, bahwa:

Pengawasan Ketenagakerjaan adalah kegiatan mengawasi dan menegakkan pelaksanaan peraturan perundangundangan di bidang ketenagakerjaan. Unit kerja pengawasan ketenagakerjaan pada instansi yang lingkup tugas dan tanggung jawabnya di bidang ketenagakerjaan pada Pemerintah Pusat adalah unit kerja pengawasan ketenagakerjaan pada Kementerian yang menangani urusan di bidang ketenagakerjaan sesuai dengan ketentuan peraturan perundang-undangan.

Selanjutnya, dalam Pasal 2 Perpres Pengawasan Ketenagakerjaan, dikatakan bahwa:

Pengawasan ketenagakerjaan dilakukan dalam satu kesatuan sistem pengawasan ketenagakerjaan yang terpadu, terkoordinasi, dan terintegrasi yang meliputi:
a. Unit kerja pengawasan ketenagakerjaan;
b. Pengawas Ketenagakerjaan; dan
c. Tata cara pengawasan ketenagakerjaan.

\section{B.4. Rendahnya Tingkat Kesadaran dan Kepedulian Pengusaha Terhadap Pemenuhan Hak Tenaga Kerja}

Dewasa ini penggunaan model PKWT, sangat diminati oleh sebagian besar pengusaha, jika di bandingkan model perjanjian kerja waktu tidak tertentu (PKWTT). Di sinilah letak timbulnya perselisihan kepentingan antara pekerja dengan pengusaha, di mana satu pihak, yaitu pekerja lebih memilih model PKWTT, karena faktor jaminan job security, sedang pihak pengusaha lebih berminat pada model PKWT, karena jenis dan sifatnya tidak tetap. Hal ini dampak dari latar belakang dan kepentingan yang tidak sama antara pihak pengusaha dan sisi lain, yakni pihak pekerja.

Fenomena ini terwujudkan dalam adegan, di mana pengusaha melakukan pemutusan hubungan kerja (PHK) terhadap pekerja tetap, dan selanjutnya mengangkat kembali dengan pola perjanjian kerja waktu tertentu, bahkan tidak sedikit menggunakan model outsourcing. Dalam kondisi demikian ini, pekerja tidak ada solusi lain, kecuali menerima tawaran untuk perekrutan dengan model PKWT atau outsourcing.

Implementasi dari PKWT, cenderung beraneka macam ragam, ada yang mematuhi kehendak hukum, ada pula penyimpangannya terhadap hukum. Kondisi ini disebabkan kurang disiplinnya pihak pengusaha dalam melaksanakan perintah hukum, justru yang tampak adanya potensi pensiasatan terhadap 
hadirnya hukum. Jika hukum hendak ditegakkan harus memenuhi elemen-elemen sebagai berikut, yakni:

Substansial (kaidah) hukum, struktural (penegak) hukum, kultural hukum dan aspek manajerial (administrasipengelolaan) hukum. Keempat unsur tersebut wajib bergerak secara bersamasama dan seirama. Ketimpangan salah satu aspek akan berdampak terhadap efektif dan tidaknya gerak hukum. ${ }^{10}$

Selain itu aspek lain dapat diikutkan dalam mewujudkan tegaknya hubungan kerja, yakni melalui pendekatan ajaran Pancasila ${ }^{11}$ :

Pertama, bahwa pekerja dan pengusaha harus menerima serta percaya, segala yang dimiliki sebagai amanah dari Allah untuk dapat dimanfaatkan bagi kepentingan masyarakat, serta pengabdian terhadap bangsa-negara.

Kedua, pekerja dan pengusaha mempunyai ikatan timbal balik serta bernilai kemanusiaan, cinta terhadap kebersamaan yang memiliki kepribadian, kehormatan, serta harga diri.

Ketiga, tidak ada diskriminasi golongan, sara, agama, dan tidak membedakan antara pria dan wanita dalam hubungan kerja antara pekerja dengan pengusaha.
Keempat, pekerja dan pengusaha harus saling membantu serta berupaya mencari persesuaian paham, mengutamakan musyawarah dalam membuat putusan bagi kepentingan bersama.

Kelima, pekerja maupun pengusaha harus selalu berupaya memperbaiki kondisi kerja, dan peningkatan kesejahteraan. Selain itu setiap orang harus menerima imbalan atau penghargaan sesuai peran dan kemampuannya.

Pemerintah sendiri sebagai pelaksana dari amanatPasal 102 ayat(2)UUKetenagakerjaan, tidak dapat melaksanakan fungsi penindakan karena hukum tidak mengatur mengenai sanksi terhadap pihak pengusaha yang melakukan perubahan status dari PKWTT ke model PKWT. Pada umumnya, jika ada perusahaan yang melakukan perubahan status tersebut, pihak pemerintah hanya bisa menghimbau untuk tidak melakukan tindakan sepihak yang merugikan pekerja. Himbauan pemerintah tidak pernah mendapat tanggapan yang positif dari pengusaha. Dengan perubahan status secara sepihak, maka eksistensi pekerja belum mendapat suatu perlindungan hukum sesuai prinsip equality before the law, dalam negara hukum yang menganut prinsip the rule of law.

10 A. Mukhtie Fadjar, Keprihatinan Memudarnya Penegakan Hukum Dan Kewibawaan Hukum Di Indonesia: Suatu Refleksi Kritis Provokatif, Buletin Forum Doktor, Malang, Edisi Ke-2, 2011, hlm. 5.

11 Filsafat Pancasila, ajaran yang mengandung nilai fundamental, yakni theisme religius, dan hal ini dapat dilukiskan dalam makna sila Pancasila yang menjadi dasar perekat sesame manusia, alam, negara dan Tuhan. Dengan nilai Pancasila tersebut, akan tercipta hubungan harmonis, sejahtera dan terjalinnya keseimbangan hak dan kewajiban sesama manusia. Lihat M. Noor Syam, Dasar Filsafat Ilmu, Laboratorium Pancasila, Universitas Negeri Malang, 2000, hlm. 201-202. 
C. Upaya Mengatasi Hambatan dalam Pelaksanaan Pemenuhan Jamsostek sebagai Wujud Perlindungan Hukum bagi Tenaga Kerja dengan Sistem PKWT

\section{C.1. Upaya Pemerintah Pusat}

Penerbitan Peraturan Sistem Kerja Kontrak/Outsourcing/PKWT oleh Pemerintah sebagai Bentuk Pengawasan.

Untuk melindungi pekerja dari permasalahan ketenagakerjaan yang kompleks, pemerintah mengeluarkan Undang-undang Ketenagakerjaan. Namun, perlindungan tersebut sebagian besar hanya berlaku bagi tenaga kerja dengan status tetap atau yang terikat dengan sistem PKWTT. Sedangkan bagi tenaga kerja dengan sistem PKWT sebagaimana dijelaskan pada bab sebelumnya, pengaturannya hanya diatur dalam Keputusan Menteri.

Adanya pembagian tenaga kerja dengan sistem PKWT dan PKWTT, berawal dari adanya pekerjaan yang memang membutuhkan waktu tertentu (terbatas) dalam pelaksanaan pekerjaannya. Dari kedua jenis pekerjaan untuk waktu tertentu tersebut di atas, sistem PKWT didasarkan atas jangka waktu membawa atau menimbulkan implikasi bagi tenaga kerja. ${ }^{12}$

Praktik-praktik yang menyimpang dari ketentuan undang-undang ini merupakan salah satu dari tuntutan tenaga kerja pada saat melakukan demonstrasi besarbesaran. ${ }^{13}$ Kondisi tenaga kerja yang sudah memprihatinkan, ditambah adanya diskriminasi perlindungan terhadap tenaga kerja dengan sistem kerja PKWT menambah keprihatinan itu.

Terlepas dari tujuan pengusaha untuk meningkatkan daya saing dan efisiensi, juga tujuan pengusaha agar dapat menciptakan kesempatan kerja seluas-luasnya, perlindungan hukum terhadap tenaga kerja juga harus tetap menjadi prioritas. Pentingnya perlindungan bagi tenaga kerja biasanya berhadapan dengan kepentingan pengusaha untuk tetap dapat bertahan (survive) dalam menjalankan usahanya. Sehingga seringkali pihak yang terkait secara langsung adalah pengusaha dan tenaga kerja. ${ }^{14}$

Secara umum persoalan ketenagakerjaan lebih banyak diidentikkan dengan persoalan antara tenaga kerja dengan pengusaha. ${ }^{15}$ Pemahaman demikian juga dipahami sebagian besar para pengambil kebijakan ketenagakerjaan sehingga terjadi reduksi pemahaman terhadap buruh sebagai pekerja

12 Aloysius Uwiyono, Implikasi Undang-Undang Ketenagakerjaan No. 13 Tahun 2003 Terhadap Iklim Investasi, Vol. 22 No. 5, Jurnal Hukum Bisnis, Jakarta, 2003, hlm. 10.

13 Tim Kontan, Ada Apa dengan Buruh, Majalah Kontan Vol. II/EDISI XXIII, 07-20 Mei 2006, Jakarta, 2006, hlm. 9.

14 Eggy Sudjana, Nasib dan Perjuangan Buruh di Indonesia, (Renaissan, Jakarta, 2005), hlm. 1.

15 Muslimin B. Putra, Buruh dalam Proses Penyusunan Kebijakan, Paper disampaikan pada Workshop "Kebijakan Partisipatif Peran Pemuda dalam Proses Penyusunan Perundang-undangan" yang diselenggarakan Komite Advokasi Buruh (KAB) pada tanggal 27 Juni 2005 di Gedung YLBHI Jakarta. 
dan buruh sebagai suatu profesi dan kategori sosial. Pemahaman tersebut mengakibatkan perlindungan terhadap tenaga kerja dengan sistem PKWT menjadi sangat lemah.

Keadaan demikian, hampir terjadi di berbagai daerah di Indonesia. Begitu juga di Kabupaten Murung Raya, permasalahan ketenagakerjaan yang berkaitan dengan pemenuhan hak tenaga kerja dengan sistem PKWT, khususnya dalam hal pemenuhan hak pada program jamsostek menjadi permasalahan yang perlu secepatnya di respon oleh pemerintah baik di pusat maupun di daerah.

Menghadapi realita tersebut, peran pemerintah diperlukan untuk melakukan campur tangan dengan tujuan mewujudkan ketenagakerjaan yang adil melalui peraturan perundang-undangan. ${ }^{16}$ Hubungan antara pengusaha dan tenaga kerja idealnya merupakan hubungan yang saling menguntungkan. Namun seringkali posisi tenaga kerja tidak seimbang dengan posisi pengusaha.

Kesepakatan untuk menerbitkan peraturan bersama ini ini ditandai dengan penandatanganan naskah peraturan bersama yang dilakukan oleh Menteri Tenaga Kerja dan Transmigrasi (Menakertrans) Muhaimin Iskandar dan Menteri Dalam Negeri (Mendagri) Gamawan Fauzi di Kantor
Kemnakertrans.

Dengan adanya aturan bersama Menakertrans dan Mendagri ini mempertegas fungsi dan tugas pegawai fungsional pengawasan untuk lebih optimal di dalam menjalankan tugas-tugas pengawasan. Menurutnya Muhaimin Iskandar, menjelaskan bahwa:

Dengan adanya perturan ini juga dapat memberikan kepastian bahwa tenaga pengawas ketenagakerjaan di daerah tidak akan diperdayakan di bidang lain. Kalau sampai dipindahpindah atau digeser, nanti akan menjadi beban kita. Karena, jumlah pengawas saat ini sangat terbatas dan cenderung belum mencapai jumlah yang ideal. ${ }^{17}$

Saat ini yang menjadi prioritas pengawasan ketenagakerjaan upah minimum, program Jaminan Sosial Tenaga Kerja (Jamsostek), kebebasan berserikat, pelaksanaan sistem kerja PKWT dan outsourcing serta berbagai macam masalah ketenagakerjaan lainnya. Hal ini memerlukan perhatian serius dari pengawas ketenagakerjaan baik yang berada pada Pemerintah, Pemerintah Provinsi dan Pemerintah Kabupaten/Kota.

Selanjutnya, Muhaimin Iskandar

16 Lalu Husni, Hukum Ketenagakerjaan Indonesia, (Jakarta: Rajawali Pers, 2003), hlm. 12.

17 Suara Pembaharuan, Awasi Outsourcing Kemenakertrans-Kemdagri Terbitkan Peraturan, terbitan Jumat, 20 Juli 2012. 
menjelaskan, bahwa:

Jumlah pengawas ketenagakerjaan saat ini sebanyak 1.469 orang yang tersebar di seluruh Indonesia. Sedangkan jumlah perusahaan yang harus diawasi sebanyak 224.060 perusahaan. Kebutuhan ideal pengawas ketenagakerjaan dengan rasio pemeriksaan 60 perusahaan per tahun, maka dibutuhkan sebanyak 3,734 orang pengawas ketenagakerjaan. Sebaran pengawasan ketenagakerjaan ini baru menjangkau kurang lebih 300 kabupaten/kota dari sekitar 497 kabupaten/kota. Salah satu tugas pengawas ini adalah sebagai aparatur penegak hukum yang dituntut untuk mampu menjamin pelaksanaan pengawas ketenagakerjaan dapat membawa dampak positif bagi pertumbuhan ekonomi daerah. ${ }^{18}$

Demikian juga menurut Gamawan Fauzi (Mendagri), menjelaskan bahwa:

Aturan bersama ini juga bermaksud untuk memberikan kewenangan kepada daerah sekaligus sebagai media untuk mengetahui apakah daerah menjalankan sesuai aturan atau tidak. Jadi, ini nanti kami pecah lagi menjadi beberapa aturan teknis sehingga pelaksanaan pengawasan betul-betul berjalan. Masalahnya, rasio pengawas dan perusahaan juga cukup jauh. Maka itu kami minta kepada daerah untuk bisa memaksimalkan ini. ${ }^{19}$

Peraturan Bersama tersebut pada intinya memuat peran strategis Kementerian Dalam Negeri (Kemendagri) di era Otonomi Daerah (Otda) dalam mendorong dan memfasilitasi penguatan sistem pengawasan ketenagakerjaan di Pemerintah Provinsi dan Pemerintah Kabupaten/Kota dalam hal kelembagaan, personil dan ketatalaksanaan pengawasan ketenagakerjaan.

$\begin{array}{ccc}\text { Sedangkan } & \text { peran } & \text { Kementerian } \\ \text { Tenaga Kerja } & \text { dan } & \text { Transmigrasi }\end{array}$
melakukan pembinaan teknis pengawasan ketenagakerjaan dalam hal pendidikan dan pelatihan, pengangkatan pengawas ketenagakerjaan, peningkatan kapasitas pengawas ketenagakerjaan, penyelenggaraan jaringan informasi pengawasan ketenagakerjaan, penyelenggaraan rapat koordinasi provinsi dan rapat kerja teknis di Kabupaten/Kota, peningkatan kerjasama dan pengendalian pelaksanaan pengawasan ketenagakerjaan.

\section{C.2. Membentuk Komite Pengawasan Ketenagakerjaan}

Pada tingkat pemerintah pusat, Kementerian Tenaga Kerja dan Transmigrasi 
(Kemenakertrans) telah membentuk Komite Pengawasan Ketenagakerjaan. Hal ini dilakukan sebagai salah satu upaya untuk memperbaiki sistem pengawasan ketenagakerjaan. Keberadaan komite pengawasan ini akan melibatkan unsur tripartit, yang terdiri dari unsur pemerintah, organisasi tenaga kerja, serta asosiasi pengusaha. Selain itu juga melibatkan unsur penegak hukum dari Kepolisian dan Kejaksaan.

Keberdaan Komite Pengawasan Ketenagakerjaan akan mendorong pelaksanaan penegakan hukum di bidang ketenagakerjaan secara terpadu, terkoordinasi, dan terintegrasi, baik di tingkat pemerintah pusat, provinsi, maupun kabupaten/kota.

Menurut Muhaimin Iskandar (Menakertrans), menjelaskan bahwa:

Pengawasan ketenagakerjaan merupakan perangkat terpenting untuk memastikan pelaksanaan peraturan dan perundang-undangan terkait, di antaranya terkait hubungan industrial, upah, kondisi kerja, Keselamatan dan Kesehatan Kerja (K-3), serta jaminan sosial tenaga kerja (Jamsostek). Pengawasan memainkan peran penting dalam mendorong semua pihak untuk menjalankan peraturan. Dalam hal ini juga ada tindakan pencegahan, pembinaan, pendidikan, dan jika diperlukan upaya penegakan hukum. ${ }^{20}$

$$
\text { Selanjutnya, }
$$

menurut

beliau terdapat kendala di bidang pengawasan ketenagakerjaan. Sejumlah kendala di bidang pengawasan ketenagakerjaan, antara lain:

Tidak optimalnya koordinasi antara pemerintah pusat dan daerah, minimnya infrastruktur dan peralatan teknis, perubahan dalam bentuk hubungan kerja, serta perluasan perlindungan untuk pekerja di sektor informal. Pelaksanaan otonomi daerah juga menjadi penyebab kurang efektifnya pengawasan ketenagakerjaan di Indonesia. ${ }^{21}$

Menurut data Kemenakertrans, diuraikan bahwa: Saat ini jumlah pengawas ketenagakerjaan tercatat sebanyak 2.384 orang yang menangani sekitar 216.547 perusahaan. Para pengawas ketenagakerjaan yang bertugas terdiri dari pengawas umum 1.460 orang, pengawas spesialis 361 orang, serta Penyidik Pegawai Negeri Sipil (PPNS) sebanyak 563 orang. Meskipun semua wilayah di Indonesia memiliki pengawas, mayoritas terkonsentrasi di Pulau Jawa. Selain yang merupakan aparat di Kemenakertrans, juga tersebar di Jawa Barat, Jawa Tengah, dan Jawa Timur. Untuk di luar Jawa, terbanyak di Sumatera Utara. Sedangkan provinsi dengan jumlah para pengawas ketenagakerjaan yang tergolong sedikit, di antaranya Nusa Tenggara Barat, Gorontalo, Sulawesi Barat, Maluku Utara, dan Papua Barat. ${ }^{22}$ 
Di masa mendatang, pemerintah mengharapkan semua kabupaten/kota memiliki pengawas ketenagakerjaan dengan kualitas dan kuantitas yang memadai, sehingga permasalahan yang ada bisa ditekan.

\section{C.3. Penghentian Izin Baru Perusahaan Outsourcing oleh Pemerintah}

Di tingkat pusat, pemerintah memutuskan melakukan moratorium atau menghentikan sementara pengeluaran izin baru bagi perusahaan outsourcing. Hal ini dilakukan sampai selesainya proses pendataan, verifikasi, dan penataan ulang perusahaan-perusahaan dengan sistem outsourcing.

Menteri Tenaga Kerja dan Transmigrasi

Muhaimin Iskandar mengatakan:

Langkah penghentian perizinan
perusahaan outsourcing ini
untuk mendukung pembenahan
pelaksanaan praktik outsourcing
di Indonesia selama ini. Status
moratorium (penutupan sementara)
terhadap penerbitan izin bagi
perusahaan outsourcing ini akan
diterapkan sampai selesainya
pendataan atau inventarisasi
terhadap perusahaan tersebut di
berbagai daerah. ${ }^{23}$

Pernyataan Menteri Tenaga Kerja dan Transmigrasi ini merupakan respons dari Konfederasi Serikat Pekerja Indonesia (KSPI) yang menuntut penghapusan sistem kerja kontrak dan penghapusan korupsi. Untuk itu, organisasi tenaga kerja akan dilibatkan untuk bersama-sama mengatasi permasalahan outsourcing ini melalui komite pengawas tenaga kerja. Dengan kata lain pemerintah merupakan pihak yang selalu terbuka dan siap menyelesaikan secara bersama-sama permasalahan outsourcing ini. Pemerintah pada posisi bersama para organisasi tenaga kerja untuk meyakinkan para pengusaha dalam mengawasi pelaksanaan outsourcing di perusahaan-perusahaan.

Terkait dengan langkah penghentian perizinan perusahaan outsourcing ini untuk mendukung pembenahan pelaksanaan praktik outsourcing di Indonesia, Muhaimin Iskandar menjelaskan, bahwa:

Pihaknya sebulan lalu telah menerbitkan surat edaran kepada gubernur dan bupati/walikota, lalu ditindaklanjuti oleh dinasdinas tenaga kerja di daerah untuk inventarisasi dan pendataan perusahaan outsourcing, serta jumlah pekerja outsourcing di wilayahnya masing-masing. Inventarisasi perusahaan-perusahaan outsourcing itu sekaligus sebagai upaya evaluasi terhadap perusahaan yang tidak kredibel, karena terindikasi merugikan pekerja. Apabila perusahaan outsourcing yang terdata melakukan pemerasaan beroperasi

23 Suara Surabaya, 1 September 2012 Mulai Berlaku Moratorium Nasional Tenaga Kerja Outsourcing, Terbitan 31 Agustus 2012. 
tidak kredibel, maka konsekuensinya adalah ditutupnya perusahaan secara langsung dan tidak ada izin baru, selagi perusahaan yang ada belum dibenahi. ${ }^{24}$

Selama ini penerapan sistem outsourcing di perusahaan-perusahaan cukup banyak yang menyimpang, terutama dalam hal penggajian, tunjangan, maupun hak dasar lainnya, seperti jaminan sosial. Dengan adanya penghentian sementara perizinan perusahaan outsourcing ini, membawa "angin segar" bagi tenaga kerja agar lebih diperhatikan keberadaannya dalam hal hak-hak dasar sebagai tenaga kerja.

\section{C.4. Upaya Pemerintah Daerah Kabupaten Murung Raya}

\section{C.4.1. Peran Kepala Daerah untuk Mendorong Kepesertaan Jamsostek di Daerahnya}

Upaya-upaya yang harus dilakukan untuk mengatasi hambatan dan mengoptimalkan pemenuhan hak tenaga kerja PKWT terhadap programJamsostekmerupakantanggungjawab bersama baik pemerintah (pusat-daerah), PT. Jamsostek maupun kesadaran para pengusaha yang mempekerjakan tenaga kerja dengan sistem PKWT. Dalam pemenuhan hak Jamsostek bagi tenaga kerja dengan sistem PKWT di Kabupaten Murung Raya, maka keberadaan pemerintah daerah melalui kepala daerahnya menjadi salah satu instrument untuk mendorong agar perusahaan-perusahaan di wilayah Kabupaten Murung Raya yang memperkerjakan tenaga kerja dengan sistem PKWT, untuk memberikan perlindungan hukum berupa pemenuhan hak terhadap program Jamsostek bagi pekerjanya.

Mengingat pentingnya program Jamsostek bagi tenaga kerja, Direktur Utama PT. Jamsostek (Persero) Pusat, Elvyn G Masassya: "Meminta para kepala daerah di seluruh Indonesia untuk mendorong kepesertaan Jamsostek di daerahnya. Sebab, dukungan dari pemerintah daerah sangat penting dalam melindungi pekerja melalui program-program Jamsostek". ${ }^{25}$

Menurut Elvyn G Masassya, menjelaskan bahwa:

Semakin banyak tenaga kerja menjadi peserta Jamsostek, maka mereka akan lebih terlindungi dalam bekerja. Sudah seharusnya seluruh tenaga kerja menikmati perlindungan sosial sehingga mereka bisa lebih produktif lagi. Untuk itu diperlukan peran kepala daerah untuk mendorong pengusaha dan instansi-instansi pemerintah mendaftarkan pekerja honorer, informal, sampai pekerja

25 Suara Surabaya, Peran Kepala Daerah untuk Mendorong Kepesertaan Jamsostek, Terbitan 01 September 2012. 
outsourcing di lingkungannya dalam

program Jamsostek. ${ }^{26}$

Oleh karena itu, Kepala Daerah (Bupati) Kabupaten Murung Raya menyambut baik hal tersebut dengan melalukan berbagai upaya guna mendorong peningkatan kepesertaan Jamsostek di Kabupaten Murung Raya. Sambutan baik kepala daerah ini dilimpahkan selanjutnya untuk dilaksanakan oleh instansi yang berwenang untuk menangani masalah ini, yakni Disnakertransos Kabupaten Murung Raya. Dalam hal ini dilaksanakan oleh Bidang Ketenagakerjaan, mengingat karena sampai saat ini di Kabupaten Murung Raya belum ada kantor cabang PT. Jamsostek (Persero). Menurut Heri Harsono, menjelaskan bahwa:

Langkah ini diwujudkan melalui kerja sama antara pemerintah daerah kabupaten Murung Raya dengan PT. Jamsostek (Persero) yang berkedudukan di Kota Palangka Raya Provinsi Kalimantan Tengah, seperti sosialisasi program Jamsostek maupun penerapan Komunikasi Pemasaran Terpadu (Integrated Marketing Communication-IMC). ${ }^{27}$

Berkaitan dengan penerapan Komunikasi Pemasaran Terpadu (Integrated Marketing Communication-IMC), Disnakertransos Kabupaten Murung Raya bekerjasama dengan
PT. Jamsostek (Persero) Kantor Cabang Kalimantan Tengah, telah menyelenggarakan Sosialisasi Program Jamsostek Tenaga Kerja Luar Hubungan Kerja (TK-LHK) Asuransi Kesejahteraan Sosial (Askesos) sebagai bentuk penerapan komunikasi pemasaran terpadu. Hal ini dilakukan, guna meningkatkan kesadaran baik bagi pengusaha maupun tenaga kerja dalam mengikutsertakan tenaga kerja pada program-program Jamsostek. ${ }^{28}$

Dengan adanya peran serta kepala daerah melalui dinas terkait, maka sosialisasi dan penyebaran informasi tentang programprogram perlindungan bagi pekerja di PT. Jamsostek dapat meningkatkan kesadaran bagi pengusaha akan pentingnya pemenuhan hak-hak bagi tenaga kerjanya. Sebab, pemenuhan hak yang memadai bagi tenaga kerja, tidak saja menguntungkan tenaga kerja, tetapi juga menguntungkan pengusaha. Tenaga kerja yang sejahtera, dapat berimplikasi positif bagi produktivitas perusahaan.

\section{C.4.2. Sosialisasi Program Jamsostek oleh PT. Jamsostek Cabang Kalimantan Tengah untuk Peningkatan Laju Kepesertaan Program Jamsostek}

Kantor Cabang (Kacab) PT Jamsostek (Persero) di berbagai daerah termasuk di Kalimantan Tengah bekerja sama dengan Bidang Ketenagakerjaan Disnakertransos

27 Hasil wawancara dengan Nara Sumber: Bapak Heri Harsono, ST., SH., Kabid Ketenagakerjaan Dinas Tenaga Kerja, Transmigrasi dan Sosial (Disnakertransos) Kabupaten Murung Raya, Tanggal wawancara 29 September 2012.

28 Hasil wawancara dengan Nara Sumber: Bapak Bapak Heri Harsono, ST., SH., Kabid Ketenagakerjaan Dinas Tenaga Kerja, Transmigrasi dan Sosial (Disnakertransos) Kabupaten Murung Raya, Tanggal wawancara 29 September 2012. 
Kabupaten Murung Raya terus meningkatkan sosialisasi program Jamsostek untuk tenaga kerja beserta manfaatnya. Sosialisasi juga dilakukan terkait manfaat tambahan lainnya yang bisa didapat tenaga kerja dan perusahaan peserta Jamsostek.

Pada tahun 2012 ini, PT. Jamsostek (Persero) mencanangkan 3 peningkatan, yakni peningkatan manfaat program jaminan sosial untuk tenaga kerja, pelayanan kepesertaan, dan jumlah peserta melalui sosialisasi. PT. Jamsostek (Persero) akan meningkatkan sosialisasi untuk meningkatkan kepesertaan program jaminan sosial bagi tenaga kerja. Dalam hal ini, tidak hanya pekerja formal di dalam hubungan kerja, PT. Jamsostek juga mengakomodasi jaminan sosial bagi tenaga kerja informal, khususnya di luar hubungan kerja (LHK).

Menurut Heri Harsono (sebagai pelaksana Program Jamsostek di Kabupaten Murung Raya), menjelaskan bahwa:

Jamsostek akan menggunakan seluruh alat dan media untuk menyebarkan informasi secara massal tentang program Jamsostek. Penyebaran informasi ini tidak hanya untuk menargetkan peningkatan kepesertaan dari kalangan pekerja formal, khususnya dalam hubungan kerja, PT Jamsostek juga akan merangkul pekerja informal di luar hubungan kerja (LHK) sebagaimana yang diamanatkan dalam UU Jamsostek dan UU Nomor 40 Tahun 2004 tentang Sistem Jaminan Sosial Nasional (UU SJSN). ${ }^{29}$

Selain melalui media massa, Heri Harsono menjelaskan, bahwa:

PT. Jamsostek juga akan melibatkan masyarakat luas dalam sosialisasi program jaminan sosial bagi tenaga kerja. Salah satunya perangkat kepimpinan di tingkat bawah, seperti Ketua RT dan RW. Salah satu tujuan dalam perlibatan masyarakat ini adalah untuk menarik dan meningkatkan kepesertaan dari sektor pekerja informal, khususnya yang masuk kategori luar hubungan kerja (LHK). ${ }^{30}$

Selain sosialisasi tentang program jaminan sosial beserta manfaatnya, Jamsostek juga akan mengintensifkan pelaksanaan Gerakan Nasional Wajib Jamsostek dengan melibatkan seluruh pemangku kepentingan, serta metode jemput bola dengan mendatangi perusahaanperusahaan dalam rangka mengsosialisasikan program serta manfaat program jaminan

29 Hasil wawancara dengan Nara Sumber: Bapak Heri Harsono, ST., SH., Kabid Ketenagakerjaan Dinas Tenaga Kerja, Transmigrasi dan Sosial (Disnakertransos) Kabupaten Murung Raya, Tanggal wawancara 29 September 2012.

30 Hasil wawancara dengan Nara Sumber: Bapak Heri Harsono, ST., SH., Kabid Ketenagakerjaan Dinas Tenaga Kerja, Transmigrasi dan Sosial (Disnakertransos) Kabupaten Murung Raya, Tanggal wawancara 29 September 2012. 
sosial bagi tenaga kerja akan diiringi dengan pemberian manfaat tambahan.

\section{C.5. Peningkatan Peran Serta Organisasi Tenaga Kerja di Kabupaten Murung Raya dalam Memperjuangkan Pemenuhan Hak Jamsostek bagi Tenaga Kerja dengan Sistem PKWT}

Organisasi tenaga kerja dibentuk oleh para tenaga kerja dengan memastikan bahwa kedudukan dan hak mereka sebagai tenaga kerja dapat seimbang dengan kewajiban yang mereka lakukan untuk pengusaha. Dalam hubungan tenaga kerja dengan majikan atau pengusaha, tidak dapat dipungkiri bahwa kedudukan tenaga kerja lebih rendah dan kadangkala itu mengakibatkan kesewenangwenangan para majikan-pengusaha terhadap tenaga kerjanya.

Dalam UU Serikat Pekerja/Serikat Buruh dijabarkan apa yang menjadi tujuan organisasi tenaga kerja yaitu: "Guna memberikan perlindungan, pembelaan hak dan kepentingan, serta meningkatkan kesejahteraan yang layak bagi pekerja/buruh dan keluarganya". Peran serikat buruh dalam menyuarakan aspirasi dan partisipasi dalam pembangunan pada dasarnya termasuk hak atas pembangunan. Partisipasi dalam pembangunan mengandung arti bahwa individu atau kelompok akan menikmati hasilhasil pembangunan dengan hak berserikat yang terjamin. Secara konseptual maka melalui organisasi tenaga kerja diharapkan bahwa:

1. Dapat berpartisipasi secara efektif dalam perumusan kebijaksanaan dan keputusan serta pelaksanaannya baik di tingkat lokal maupun nasional, sehingga aspirasi mereka benar-benar diperhatikan.

2. Merumuskan dan melakukan tugas ekonomi, sosial, politik dan budaya atas dasar pilihan sendiri berdasarkan kebijaksanaan-kebijaksanaan guna memperbaiki standard dan kualitas kehidupan mereka serta melestarikan dan mengembangkan kebudayaannya.

3. Berpartisipasi dalam memantau dan meninjau kembali proses pembangunan. ${ }^{31}$

Terkait dengan pemenuhan hak tenaga kerja terhadap program Jamsostek yang belum sepenuhnya atau terabaikan oleh perusahaan yang ada di kabupaten Murung Raya, maka keberadaan organisasi tenaga kerja menjadi salah satu pilihan utama untuk penyaluran memperjuangkan hak-hak tenaga kerja di wilayah ini. Peran organisasi tenaga kerja di wilayah ini perlu ditingkatkan guna mengakomodir kepentingan para tenaga kerja yang belum mendapatkan hak-haknya dalam program Jamsostek.

Menurut Henry Ketua SPSI di Kabupaten Murung Raya, menjelaskan bahwa:

Untuk saat ini organisasi tenaga kerja yang ada di kabupaten Murung Raya dalam memperjuangkan 
hak anggotanya terhadap program Jamsostek yang tidak dipenuhi oleh pengusaha, telah melakukan upaya-upaya agar hak tersebut dipenuhi seperti memberikan tekanan kepada pemerintah daerah maupun pengusaha melalui sarana demonstrasi, membawa ke jalur litigasi (pengadilan) terhadap perusahaan-perusahan yang tidak mau melaksanakan kewajibanya, serta upaya lain yang mencerminkan peningkatan peran serta organisasi tenaga kerja dalam memperjuangkan hak-hak anggotanya (tenaga kerja). ${ }^{32}$

Dalam rangka peningkatan peran serta organisasi tenaga kerja tersebut melalui berbagai upaya di atas, tidak lepas dari konsep pilar perjuangan. Menurut Henry, menjelaskan bahwa:

Dalam konteks perjuangan hak-hak tenaga kerja ada beberapa pilar yang sangat berperan dalam menegakkan hak-hak tersebut dalam mewujudkan kesejahteraannya yaitu, organisasi tenaga kerja itu sendiri, Lembaga Kerjasama Tripartit, Lembaga Penyelesaian Perselisihan Hubungan Industrial, serta Lembaga Swadaya Masyarakat. ${ }^{33}$
Tindakan tegas terhadap perusahaan yang tidak melaksanakan pemenuhan Program Jamsostek bagi Tenaga Kerja dengan Sistem PKWT

Hingga kini masih banyak perusahaan yang "membandel" terhadap kewajiban untuk mengikuti program Jamsostek. Perusahaan tersebut "enggan" mendaftarkan tenaga kerjanya sebagai peserta program Jamsostek. Padahal perihal kewajiban ini sudah disosialisasikan oleh pemerintah di pusat maupun di daerah. Dari berbagai daerah dilaporkan banyak kejadian kecelakaan kerja yang tidak jarang, kecelakaan kerja itu berujung kematian pekerja. Ironisnya, keluarga korban tidak mendapatkan kompensasi apapun. Perusahaan seolah lepas tanggung jawab. Kematian tenaga kerja hanya dianggap sebagai risiko biasa dalam bisnis. Padahal dalam paradigma bisnis modern, jaminan sosial bagi pekerja adalah bentuk hak asasi manusia.

Dengan demikian, perusahaan yang tidak mengikutsertakan pekerja dalam program Jamsostek sama artinya mengabaikan aturan hukum sekaligus melanggar hak asasi manusia. Maka, perusahaan yang "membandel" seperti itu harus ditindak tegas. Dengan kata lain harus diajukan ke "meja hijau" (pengadilan). Sebagai salah satu contoh satu perusahaan di Kota Pontianak Kalimantan Barat yang

\footnotetext{
32 Hasil wawancara dengan Nara Sumber: Bapak Henry, SE., MH., Ketua SPSI Kabupaten Murung Raya, Tanggal wawancara 30 September 2012.

33 Hasil wawancara dengan Nara Sumber: Bapak Henry, SE., MH., Ketua SPSI Kabupaten Murung Raya, Tanggal wawancara 30 September 2012.
} 
harus berhadapan dengan hukum dan dibawa ke Pengadilan Negeri Pontianak, sebagai konsekuensi hukum dari perbuatan perusahaan yang tidak membayar upah pekerja dan tidak mengikutsertakan pekerjanya sebagai peserta Jamsostek.

Proses hukum terhadap
perusahaan itu dilakukan Penyidik
Pegawai Negeri Sipil (PPNS)
Ketenagakerjaan Dinas Sosial
Tenaga kerja (Dinsosnaker) Kota
Pontianak, Kalimantan Barat setelah
diketahui adanya pelanggaran
ketenagakerjaan tersebut. Saat
ini kasus ketenagakerjaan
tersebut sedang ditangani oleh
Pengadilan Negeri Pontianak
dengan dakwaan melakukan
tindak pidana pelanggaran aturan
ketenagakerjaan. ${ }^{34}$

Sesuai dengan prosedur yang ditetapkan, setiap pelanggaran yang dilakukan oleh perusahaan maka harus segera diberikan "nota pertama" sebagai peringatan untuk memperbaiki kesalahannya. Apabila masih saja mengabaikan peringatan tahap kedua dan ketiga, maka harus segera ditindaklanjuti dengan Surat Perintah Dimulainya Penyidikan (SPDP) untuk membuat Berita Acara Pemeriksaan (BAP) untuk kepentingan pengadilan. Sanksi sebagai wujud dari akibat hukum yang dapat dikenakan bagi yang melanggar ketentuan tersebut terdiri atas dua

(2) macam yaitu:

1. Ketentuan Pidana diatur dalam Pasal 183 sampai dengan Pasal 189 UU Ketenagakerjaan.

a. Pasal 183

Ayat (1): Barang siapa melanggar ketentuan sebagaimana dimaksud dalam Pasal 74, dikenakan sanksi pidana penjara singkat 2 (dua) tahun dan paling lama 5 (lima) tahun dan/atau denda paling sedikit Rp. 200.000.000,00 (dua ratus juta rupiah) dan paling banyak Rp. 500.000.000,00 (lima ratus juta rupiah).

Ayat (2): Tindak pidana sebagaimana dimaksud dalam ayat (1) merupakan tindak pidana kejahatan.

b. Pasal 184:

Ayat (1): Barang siapa melanggar ketentuan sebagaimana dimaksud dalam Pasal 167 ayat (5), dikenakan sanksi pidana penjara paling singkat 1 (satu) tahun dan paling lama 5 (lima) tahun dan/atau denda paling sedikit Rp. 100.000.000,00 (seratus juta rupiah) dan paling banyak Rp. 500.000.000,00 (lima ratus juta rupiah).

Ayat (2): Tindak pidana sebagaimana dimaksud dalam ayat (1) merupakan tindak pidana kejahatan.

34 Okezone.com, Ini Akibat Perusahaan Tak Bayar Upah dan Jamsostek, Posting 17 Januari 2012, www. google.com, diakses tanggal 27 September 2012. pukul 09.15 WIB. 
c. Pasal 185:

Ayat (1): Barang siapa melanggar ketentuan sebagaimana dimaksud dalam Pasal 42 ayat (1) dan ayat (2), Pasal 68 ayat (2), Pasal 80, Pasal 82, Pasal 90 ayat (1), Pasal 143 dan Pasal 160 ayat (4) dan ayat (7), dikenakan sanksi pidana penjara paling singkat 1 (satu) tahun dan paling lama 4 (empat) tahun dan/atau denda paling sedikit Rp. 100.000.000,00 (seratus juta rupiah) dan paling banyak Rp. 400.000.000,00 (empat ratus juta rupiah).

Ayat (2): Tindak pidana sebagaimana dimaksud dalam ayat (1) merupakan tindak pidana kejahatan.

d. Pasal 186:

Ayat (1): Barang siapa melanggar ketentuan sebagaimana dimaksud dalam Pasal 35 ayat (2) dan ayat (3), Pasal 93 ayat (2), Pasal 137, Pasal 138 ayat (1), dikenakan sanksi pidana penjara paling singkat 1 (satu) bulan dan paling lama 4 (empat) tahun dan/atau denda paling sedikit Rp. 100.000.000,00 (seratus juta rupiah) dan paling banyak Rp. 400.000.000,00 (empat ratus juta rupiah).

Ayat (2): Tindak pidana sebagaimana dimaksud dalam ayat (1) merupakan tindak pidana pelanggaran.

e. Pasal 187:

Ayat (1): Barang siapa melanggar ketentuan sebagaimana dimaksud dalam Pasal 37 ayat (2), Pasal 44 ayat (1), Pasal 45 ayat (1), Pasal 67 ayat (1), Pasal 71 ayat (2), Pasal 76, Pasal 78 ayat (2), Pasal 79 ayat (1) dan ayat (2), Pasal 85 ayat (3) dan Pasal 144, dikenakan sanksi pidana kurungan paling singkat 1 (satu) bulan dan paling lama 12 (dua belas) bulan dan/atau denda paling sedikit Rp. 10.000.000,00 (sepuluh juta rupiah) dan paling banyak Rp. 100.000.000,00 (seratus juta rapiah). Ayat (2): Tindak pidana sebagaimana dimaksud dalam ayat (1) merupakan tindak pidana pelanggaran.

f. Pasal 188:

Ayat (1): Barang siapa melanggar ketentuan sebagaimana dimaksud dalam Pasal 14 ayat (2), Pasal 38 ayat (2), Pasal 63 ayat (1), Pasal 78 ayat (1), Pasal 108 ayat (1), Pasal 111, Pasal 114 dan Pasal 148, dikenakan sanksi pidana denda paling sedikit Rp. 5.000.000,00 (lima juta rupiah) dan paling banyak Rp. 50.000.000,00 (lima puluh juta rupiah).

Ayat (2): Tindak pidana sebagaimana dimaksud dalam ayat (1) merupakan tindak pidana pelanggaran.

g. Pasal 189: Sanksi pidana penjara, kurungan dan/atau denda tidak menghilangkan kewajiban pengusaha membayar hak-hak dan/atau ganti kerugian kepada tenaga kerja atau pekerja/buruh. 
2. Sanksi Administratif diatur dalam Pasal 190 UU Ketenagakerjaan

Pasal 190:

Ayat (1): Menteri atau pejabat yang ditunjuk mengenakan sanksi administratif atas pelanggaran ketentuan-ketentuan sebagaimana diatur dalam Pasal 5, Pasal 6, Pasal 15, Pasal 25, Pasal 38 ayat (2), Pasal 45 ayat (1), Pasal 47 ayat (10, Pasal 48, Pasal 87, Pasal 106, Pasal 126 ayat (3) dan Pasal 160 ayat (1) dan ayat (2) Undang-undang ini serta peraturan pelaksanaannya;

Ayat (2): Sanksi administratif sebagaimana dimaksud dalam ayat

(1) berupa:

a. Teguran;

b. Peringatan tertulis;

c. Pembatasan kegiatan usaha;

d. Pembekuan kegiatan usaha;

e. Pembatalan persetujuan;

f. Pembatalan pendaftaran;

g. Penghentian sementara sebagian atau seluruh alat produksi;

h. Pencabutan ijin.

Ayat (3): Ketentuan mengena administratif sebagaimana dimaksud dalam ayat (1) dan ayat (2) diatur lebih lanjut oleh Menteri.

Untuk mendukung pemerintah daerah guna menegakkan hukum agar dipatuhinya pemenuhan hak Jamsostek bagi tenaga kerja dengan sistem PKWT, dalam hal ini Disnakertransos Kabupaten Murung Raya melakukan upaya meningkatkan ${ }^{35}$ kinerja dan profesionalitas petugas pengawasan ketenagakerjaan, terutama Penyidik Pegawai Negeri Sipil (PPNS) yang berwenang melakukan penyidikan terhadap kasus-kasus pelanggaran ketenagakerjaan.

Dalam menegakkan pengawasan ketenagakerjaan para petugas pengawas memberikan pengawasan secara ketat terhadap penerapan waktu kerja upah, Jamsostek, TKI, Tenaga Kerja Anak serta Tenaga Kerja Asing di perusahaan-perusahaan. Selain itu, pengawasan pun dilakukan terhadap sektor Keselamatan dan Kesehatan Kerja (K3), kelembagaan Keselamatan dan Kesehatan Kerja (K3), keahlian Keselamatan dan Kesehatan Kerja (K3), serta sistem manajemen Keselamatan dan Kesehatan Kerja (K3) yang ada di perusahaan-perusahaan.

Menurut data yang diperoleh penulis, secara nasional (di Indonesia) bahwa angka pelanggaran terhadap Norma Keselamatan dan Kesehatan Kerja (K3) masih terbilang cukup tinggi. Menurut data Kemenakertrans pada tahun 2011, jumlah perusahaan yang mendapat peringatan berupa nota pemeriksaan tahap I sebanyak 7.468 perusahaan dan jumlah perusahaan yang mendapat peringatan keras berupa nota pemeriksaan tahap II berjumlah 1.472 perusahaan. Sementara itu, perusahaan yang telah dinyatakan melakukan

35 Kementerian Nakertrans: Upaya mempercepat peningkatan kualitas dan kuantitas pengawas ketenagakerjaan dengan melakukan pendidikan dan pelatihan pengawas ketenagakerjaan serta melakukan upgrading dan bimbingan teknis secara terus menerus. 
pelanggaran aturan ketenagakerjaan dan norma K3 mencapai 3.848 perusahaan sedangkan jumlah perusahaan yang telah disidik dan di nota untuk diajukan ke pengadilan berjumlah 78 perusahaan. Saat ini jumlah pengawas ketenagakerjaan tercatat sebanyak 2.384 orang, untuk menangani sekitar 216.547 perusahaan. Para pengawas ketenagakerjaan yang saat ini tengah bertugas terdiri dari pengawas umum: 1.460 orang, pengawas spesialis: 361 orang, Penyidik Pegawai Negeri Sipil (PPNS): 563 orang. ${ }^{36}$

\section{Simpulan}

Pelaksanaan program Jamsostek bagi tenaga kerja dengan (PKWT) belum sepenuhnya diimplementasikan oleh perusahaan-perusahaan di Kabupaten Murung Raya. Bahkan hampir 50\% perusahaan di kabupaten Murung Raya belum mengikuti program jamsostek. Kurangnya kesadaran pengusaha dalam melaksanakan program jamsostek disebabkan berbagai faktor yang salah satunya terkait dengan penghematan pengeluaran keuangan perusahaan.

Hambatan dalam pelaksanaan pemenuhan hak Jamsostek sebagai wujud perlindungan hukum bagi tenaga kerja dengan sistem PKWT di Kabupaten Murung Raya yaitu hambatan yang berkaitan dengan pengaturan tentang Program Jamsostek bagi tenaga kerja dengan sistem PKWT, hambatan yang berkaitan dengan lemahnya sistem pengawasan, belum optimalnya peran pengawas ketenagakerjaan, dan rendahnya tingkat kesadaran dan kepedulian perusahan terhadap pemenuhan hak tenaga kerja.

Upaya untuk mengatasi hambatan dalam pelaksanaan pemenuhan hak Jamsostek sebagai wujud perlindungan hukum bagi tenaga kerja dengan sistem PKWT di Kabupaten Murung Raya yaitu Upaya pemerintah pusat dilakukan dengan Penerbitan Peraturan Sistem Kerja Kontrak/outsourcing/ PKW oleh Pemerintah sebagai bentuk pengawasan, membentuk komite pengawasan ketenagakerjaan, penghentian izin baru perusahaan outsourcing oleh Pemerintah. Upaya Pemerintah daerah yaitu peran dan tugas Kepala Daerah untuk mendorong kepesertaan Jamsostek di daerahnya, sosialisasi program Jamsostek oleh PT. Jamsostek Cabang Kalimantan Tengah. Peningkatan peran serta organisasi tenaga kerja di Kabupaten Murung Raya dan tindakan tegas terhadap perusahaan yang tidak melaksanakan pemenuhan program Jamsostek bagi tenaga kerja dengan Sistem PKWT. 


\section{DAFTAR PUSTAKA}

A. Mukhtie Fadjar, 2011. Keprihatinan Memudarnya Penegakan Hukum Dan Kewibawaan Hukum

Di Indonesia: Suatu Refleksi Kritis Provokatif, Buletin Forum Doktor, Malang, Edisi Ke-2, 2011

Agusmidah, Peran Serikat Pekerja/Serikat

Buruh Menghadapi Era Globalisasi,

USU Repository, www.google.com., diakses tanggal 28 September 2012.

Aloysius Uwiyono, 2003. Implikasi Undang-undang Ketenagakerjaan No. 13 Tahun 2003 Terhadap Iklim Investasi, Vol. 22 No. 5, Jurnal Hukum Bisnis, Jakarta.

Andari Yurikosari, 2010. Pemutusan Hubungan Kerja di Indonesia, Penerbit Fakultas Hukum Universitas Indonesia, Jakarta.

Djoko Heroe Soewono, Perjanjian Kerja

Waktu Tertentu: Tinjauan dari Perspektif Juridis Sosiologis-

Reflektif Kritis, Jurnal Elektronik Universitas Kediri, 25 Juli 2012.

Eggy Sudjana, 2005. Nasib dan Perjuangan

Buruh di Indonesia, Renaissan, Jakarta.

Erman Rajagukguk, Penemuan Hukum di Indonesia: Menjaga Persatuan, Memulihkan Ekonomi dan Memperluas Kesejahteraan Sosial, Pidato Dies Natalis dan Peringatan Tahun Emas Universitas Indonesia (1950-2000), Kampus UI Depok Jakarta, 5 Februari 2000.
H. Djaali, dkk, 2003. Hak asasi Manusia, Suatu Tinjauan Teoritis dan Praktis, Penerbit Restu Agung, Jakarta.

Lalu Husni, 2003. Hukum Ketenagakerjaan Indonesia, Rajawali Pers, Jakarta.

M. Noor Syam, 2000. Dasar Filsafat Ilmu, Laboratorium Pancasila, Universitas Negeri Malang.

Muslimin B. Putra, Buruh dalam Proses Penyusunan Kebijakan, Paper disampaikan pada Workshop "Kebijakan Partisipatif Peran Pemuda dalam Proses Penyusunan Perundangundangan" yang diselenggarakan Komite Advokasi Buruh (KAB) pada tanggal 27 Juni 2005 di Gedung YLBHI Jakarta

Okezone.com, Ini Akibat Perusahaan Tak Bayar Upah dan Jamsostek, Posting 17 Januari 2012, www.google.com.

Tim Kontan, 2006. Ada Apa dengan Buruh, Majalah Kontan Vol. II/EDISI XXIII, 07-20 Mei 2006, Jakarta.

Suara Pembaharuan, Awasi outsourcing Kem e n a e r trans-Kemdagri Terbitkan Peraturan, terbitan Jumat, 20 Juli 2012.

Suara Surabaya, 1 September 2012 Mulai Berlaku Moratorium Nasional Tenaga Kerja Outsourcing, Terbitan 31 Agustus 2012.

Suara Surabaya, Peran Kepala Daerah untuk Mendorong Kepesertaan Jamsostek, Terbitan 01 September 2012. 